\title{
Palaeolithic occupation of the Mehran Plain in Southwestern Iran
}

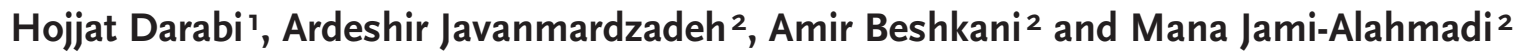 \\ 1 Department of Archaeology, Razi University, Kermanshah, IR \\ hojjatdarabi@gmail.com \\ 2 Department of Archaeology, University of Tehran, Tehran, IR
}

\begin{abstract}
In terms of Palaeolithic studies, the Mehran Plain is already known due to the discovery of the Amar Merdeg site in 1999. But in spite of the high potential for occupation in different periods, the prehistoric settlement patterns of the plain had not been identified until the present survey in 2010, which resulted in the discovery of 15 Palaeolithic sites. Of these, 9 sites contain both Lower and Middle Palaeolithic remains and 3 more sites are attributed to the Middle Palaeolithic as well 3 sites to Upper Palaeolithic period and beyond. The distribution pattern indicates that easy access to raw materials, which are now visible among the chert pebbles scattered over hillocks on the plains, was the main reason to establish settling.
\end{abstract}

IZVLEČEK - V paleolitskih študijah je ravnica Mehran znana po odkritju najdišča Amar Medreg leta 1999. Kljub velikemu potencialu poselitveni vzorci v ravnici niso bili prepoznani use do najnovejših terenskih pregledov leta 2010, ko smo odkrili 15 paleolitskih najdišč. Od teh 9 najdišč vsebuje starejše in srednje paleolitske artefakte; 3 najdǐ̌ča smo uvrstili v obdobje srednjega paleolitika in prav tako 3 najdǐ̌ča v obdobje mlajšega paleolitika in kasnejših obdobij. Poselitveni vzorec kaže, da je bil glavni razlog za naselitev lažji dostop do kamnitih surovin, ki so danes vidne na površju kot roženi prodniki, razpršeni po vzpetinah v ravnici.

KEY WORDS - Paleolithic; Mehran Plain; settlement pattern

\section{Introduction}

Palaeolithic archaeology in Iran has been divided into three main stages; in the first stage, from the early $20^{\text {th }}$ century to the late 1970 s, all researches were conducted by western archaeologists building a foundation on which later researches rested; the second stage sees a 20-year gap in Palaeolithic studies, and the third stage began with the reopening of the fields to non-Iranian and also Iranian researchers, which led to the survey and excavation of a handful of new Palaeolithic sites since the early $21^{\text {st }}$ century (Vahdati Nasab 2011). However, serious studies go back to the mid-20th century, when Carletoon Coon (1951) and then others carried out investigations in different areas (Smith 1986; Olszewski, Dibble 1993). The third stage coincided with research which mostly directed by Iranian archaeolo- gists or jointly (Roustaei et al. 2002; 2004; Otte et al. 2009). In this ongoing stage, some sites were also revisited (Roustaei et al. 2004; Otte et al. 2009) and some areas have been studied for the first time (Mohammadifar, Motarjem 2008; Biglari et al. 2000; Biglari, Heidary 2001). In this regard, the Mehran plain in the southern part of Ilam province in southwestern Iran, adjacent to the Iraqi border, was surveyed in the late 1990s, resulting in the discovery of Palaeolithic remains at Amar Merdeg (Biglari et al. 2000; Biglari, Shidrang 2006; Nokandeh 2010). The plain is approximately $400 \mathrm{~km}^{2}$ in area, bounded by Pashmin Mountains to the north, the Hamrin Mountains to the south, the Iraqi border to the west and Mt. Anaran to the east (Fig. 1). It is also fed by three main rivers, the Konjam Cham, Gavi and Chan- 
goleh, which all spring in the northern mountains and flow into Iraq.

\section{Archaeological project of the Meh- ran Plain: Paleolithic survey}

Archaeological studies of the Mehran Plain were begun in the mid-1990s by Alimohammad Khalilian, who launched an investigation to identify all ancient remains, then continued by Gabriel Nokandeh resulting in 62 sites from various periods being recorded (Nokandeh 2010). Later research focused primarily on the Neolithic period (Darabi, Fazeli 2009; Zeidi pers. comm.). Geographically, the plain is located amidst three archaeologically important regions of Mesopotamia and the Susa plains to

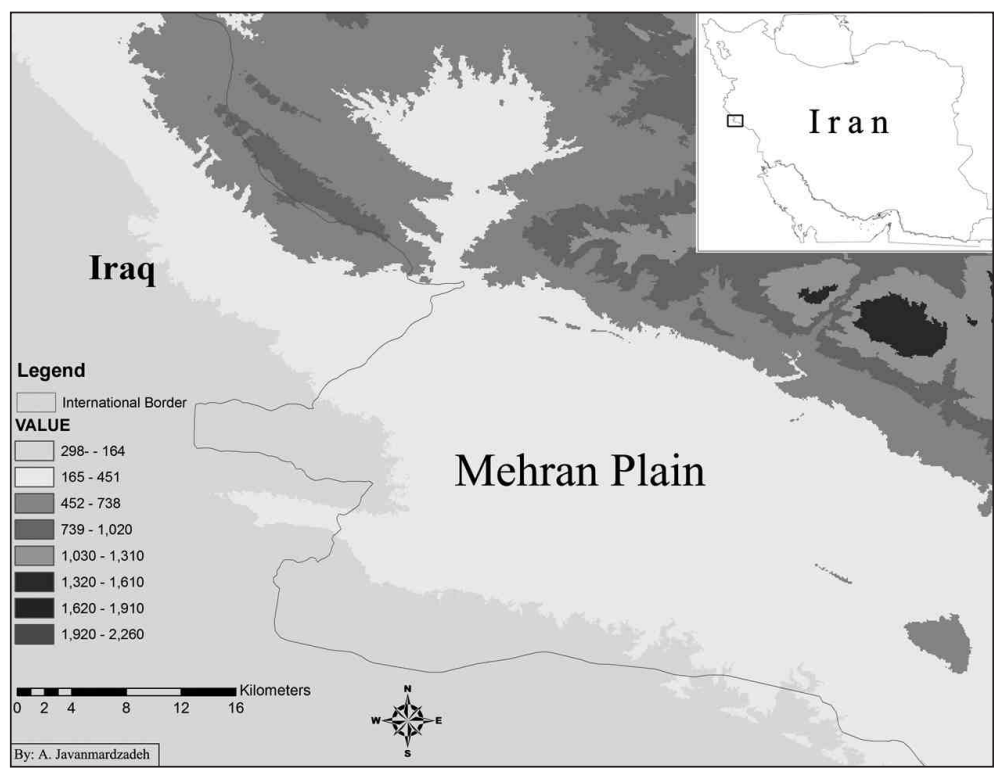

Fig. 1. Map showing the geographical position of the Mehran Plain. the west and east, respectively, and the Central Zagros to the north. Thus the Mehran Plain is much more important in terms of relationships between these regions. However, due to political problems such as Iraq-Iran war, very little was known about the prehistoric settlement change and continuity of the plain until a long-term research project named 'Archaeological Project of the Mehran Plain' was begun in 2010. Although the project is mainly focused on investigating both Neolithic and Chalcolithic periods, we also based one of our survey objectives on identifying Palaeolithic remains, which will be discussed in this paper. The survey directed by $\mathrm{H}$. Darabi in the spring of 2010 resulted in the discovery of 36 prehistoric sites ( $\mathrm{Mr} 001-\mathrm{Mr} 036)$, of which 15 sites are attributed to various periods of the $\mathrm{Pa}$ laeolithic on the basis of the stone finds. Table 1 shows basic information on the sites. We proposed that the northern calcareous mountains with their numerous caves and shelters and also the Pleistocene hillocks on the plain not buried by the later Holocene alluviation were occupied during the Palaeolithic. Due to a shortage of time, the survey coverage was limited to the plain itself, while the northern mountainous areas were not investigated. So, we have the plain information itself and hope to complete our research in future. However, 22 localities were mapped, of which 16 are techno-typologically dated. As the prehistoric settlements were affected by environmental and geomorphological elements, this needs to be taken into account here. The Mehran plain has an elevation above sea level varying from $150 \mathrm{~m}$ in the west up to $400 \mathrm{~m}$ in the east and is buried under post-Pleistocene alleviation, with de- posits of varying thickness. The north-northeastern mountain areas were formed during the second and third geological era from various lime stones. It should be noted that the northern mountains are oriented northwest-southeast parallel to the Zagros chain. Geologically, the plain is located in the midst of both tectonic zones of the Zagros fault and lowlands of Khuzistan (Brookes 1989). But the prominent features in the plain are the numerous scattered hillocks which may have been formed by the accumulation of catastrophic flood alluviation during the Pleistocene (Biglari et al. 2000.749). The

\begin{tabular}{|l|c|c|c|c|}
\hline \multirow{2}{*}{ Site name } & \multicolumn{2}{|c|}{ Coordination } & $\mathbf{Z}$ (a.s.l) & Area $(\mathbf{m})$ \\
\cline { 2 - 3 } & $\mathbf{X}$ & $\mathbf{Y}$ & & \\
\hline MRo03 & 644540 & 3657252 & 276 & $200 \times 200$ \\
\hline MRo05 & 645723 & 3657736 & 304 & $50 \times 50$ \\
\hline MRo09 & 639304 & 3664307 & 366 & $500 \times 200$ \\
\hline MRo10 & 640592 & 3668975 & 507 & $20 \times 30$ \\
\hline MRo12 & 635994 & 3662657 & 335 & $135 \times 50$ \\
\hline MRo13 & 634444 & 3662671 & 333 & $300 \times 1000$ \\
\hline MRo14 & 637495 & 3664775 & 370 & $400 \times 200$ \\
\hline MRo15 & 617684 & 3670705 & 248 & $650 \times 250$ \\
\hline MRo16 & 617345 & 3671048 & 238 & $350 \times 150$ \\
\hline MRo17 & 615654 & 3672515 & 262 & $2000 \times 1000$ \\
\hline MRo18 & 614262 & 3672985 & 256 & $2100 \times 1000$ \\
\hline MR021 & 612096 & 3671599 & 217 & $1600 \times 800$ \\
\hline MRo23 & 611926 & 3667063 & 174 & $60 \times 50$ \\
\hline MRo34 & 646242 & 3664232 & 472 & $12 \times 6 \times 3$ \\
\hline MR035 & 644693 & 3659031 & 318 & $600 \times 300$ \\
\hline MRo36 & 644696 & 3659031 & 318 & $4000 \times 2200$ \\
\hline
\end{tabular}

Tab. 1. Table showing the variant primary information of the discovered sites. 
source of the sediments is the Aghajari formation and the overlying and Bakhtiyari conglomerate of the Zagros front ranges (Eyvazi 1995). Abundant lumps of chert pebble, cobbles and nodules are found on the surface of most of the hillocks, which in terms of analysing the distribution pattern of Palaeolithic occupation are very significant (Brantingham 2003; Biglari

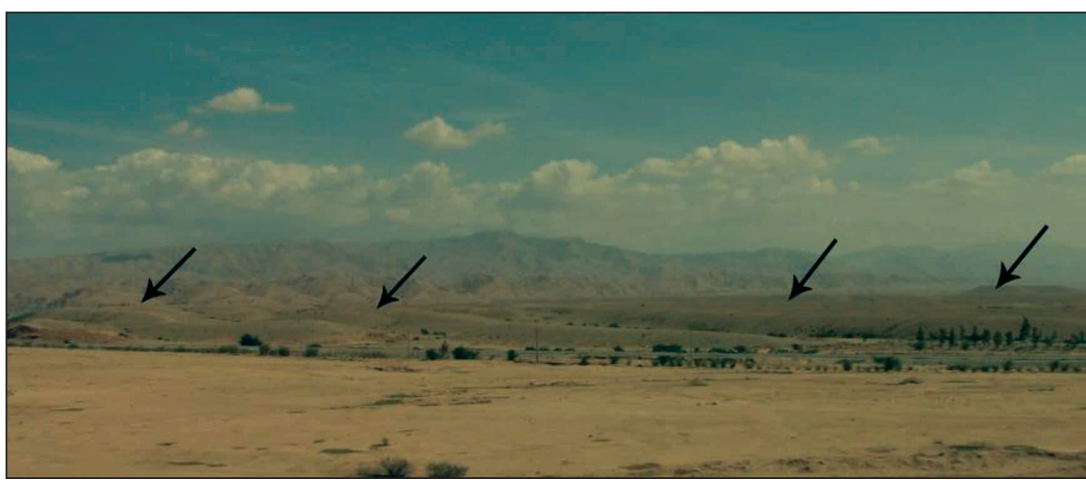

Fig. 2. General view of Amar Merdeg as a cluster of hills, looking east.
2004; Heydari 2004; 2007) and we will refer to this below.

\section{Lower Palaeolithic}

As mentioned, 9 sites contain a Lower Palaeolithic assemblage, which enhances our information on this period in the plain, as it was already known from only one site called Amar-Merdeg (Fig. 4). It should be noted that since this site covers a cluster of separate hills, we recorded it again as four localities in order to take more samples to be studied more exactly.

Mr003: where the Lashtar stream flows to the Changloleh River at the easternmost area of the plain, an assemblage of chipped stones was scattered over the left bank. Indeed, the site was established on a conglomerate terrace. Typologically, the pebbles, flakes and a small quantity of unifacial and bifacial choppers and unipolar cores were mainly by-products of working chert pebbles.

Mr009: some $2 \mathrm{~km}$ to the north of Chalab village, many hills are visible over an area of $c .1 .5 \mathrm{~km}^{2}$ at an elevation of $366 \mathrm{~m}$ above sea level. Chert pebble, cobble and nodule are present on the hilly surfaces, these were used to produce various stone tool such as polyhedron cores (Fig. 3. 3), a partially bifacial chopper, a pointed chopper

5 and bifacial tools (Fig. 3.4-6). We also found a single hand-axe like which was heavily flaked (Figs. 3.1; 5.1). The chipped stone has a different concentration on the basis of the density of raw material.

Mr012: $5 \mathrm{~km}$ to the southwest of $\mathrm{Mr} 009$ and $1 \mathrm{~km}$ to the west of Chalab village, abundant chipped stone is scattered among the chert raw material similarly to what is seen at the other sites, although most of the samples collected are attributable to later Palaeolithic periods, of which one bifacial tool with $6 \mathrm{~cm}$ in length is notable. The distal end of this tool is rounded in form and was unretouched. However, the proximal end was flaked on one side, while
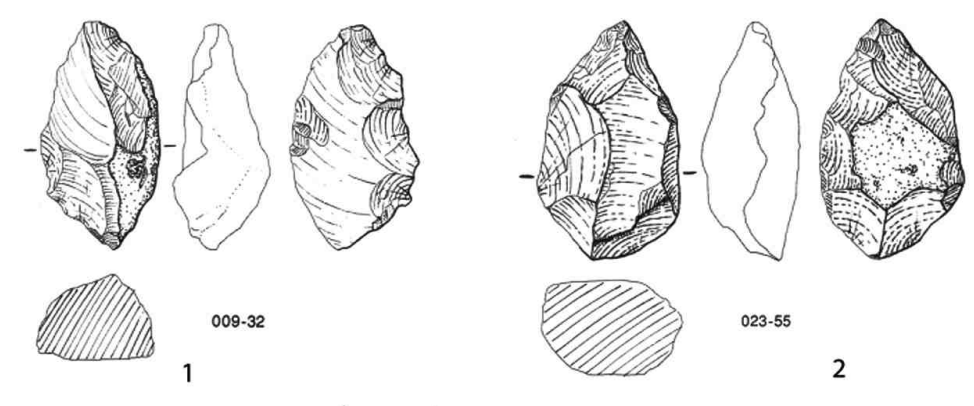

2
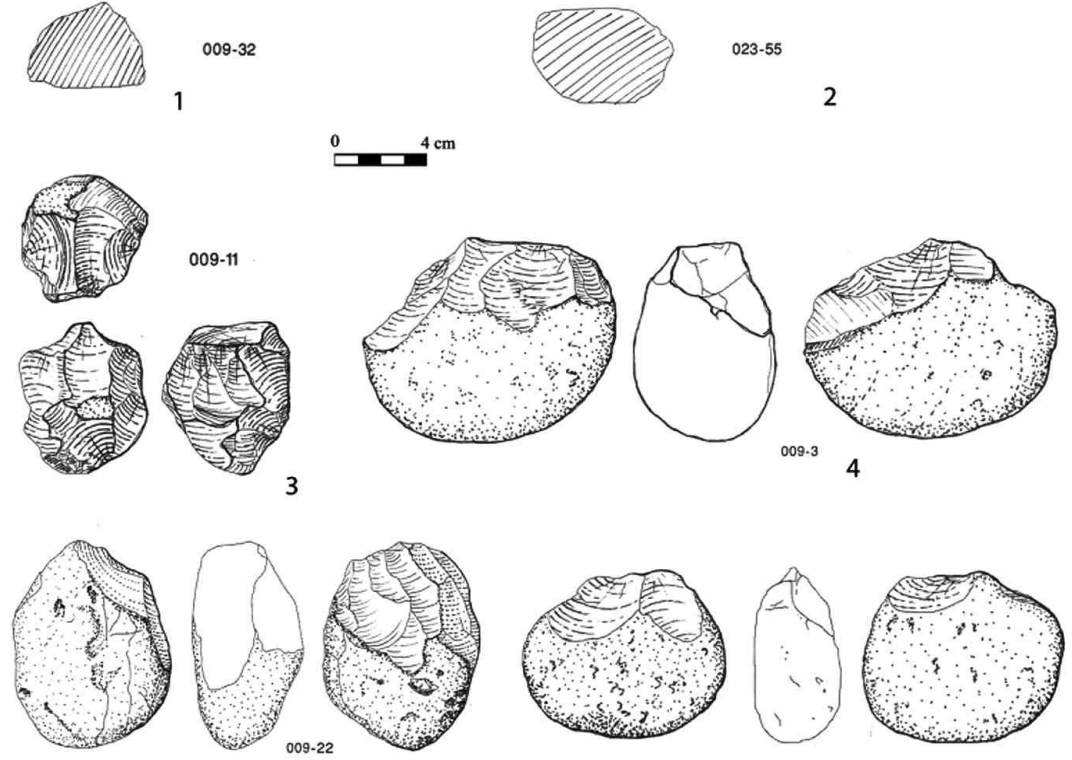

6

$009-6$

Fig. 3. Samples of Lower Palaeolithic tools. 1 bifacial. 2 hand-axe. 3 polyhedron. 4, 6 partially bifacial choppers. 


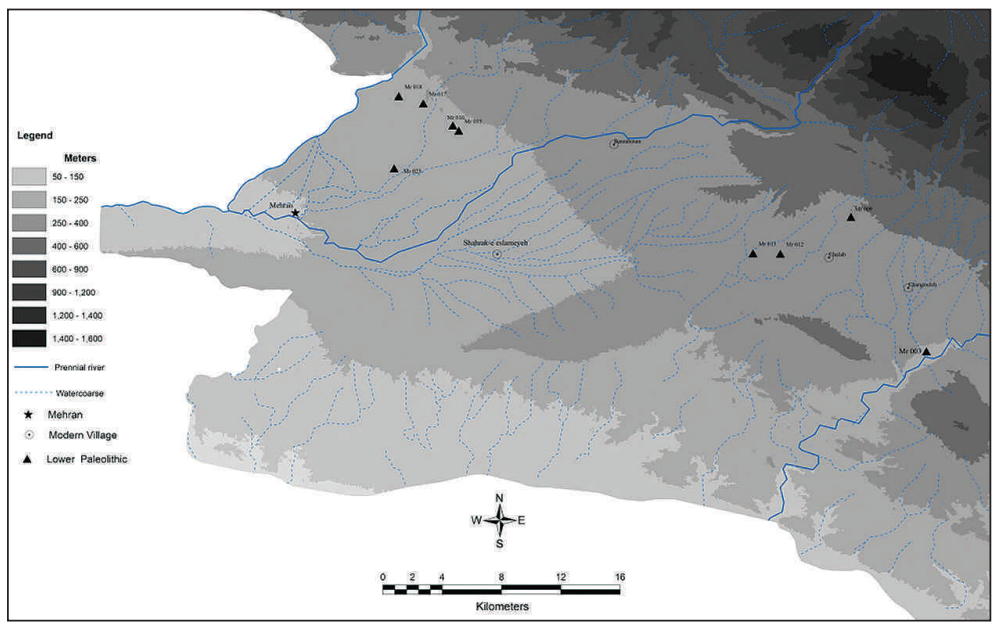

Fig. 4. Map showing the distribution pattern of Lower Palaeolithic sites on the Mehran Plain.

the other side is cortical. This bifacial tool is heavily patinated, like those found in Amar Merdeg (Biglari pers. comm.).

Mr013: this site, located some $4 \mathrm{~km}$ to the west of Chalab village on the northern edge of the MehranDehluran road, extends over an area of about less than $2 \mathrm{~km}^{2}$. Of the collected samples, two polyhedrons made from chert pebbles are attributed to Lower Palaeolithic period.

Mr015-16-17-18 (Amar Merdeg Collection): a cluster of hills extending over an area of $c .10 \mathrm{~km}^{2}$ less than $1 \mathrm{~km}$ to the east of the Konjan-Cham river and $7 \mathrm{~km}$ to the north of the town of Mehran, at 250$300 \mathrm{~m}$ above sea level (Fig. 2). As a result of the previous survey in 1999, some of the samples collected from the site such as chopping tools were attributed to the Lower Palaeolithic (Biglari et al. 2000.749). Additional fieldwork in 2001 and 2004 resulted in the discovery of four bifaces and partial bifaces and more core-choppers (Biglari, Shidrang 2006.164). Indeed, Amar Merdeg is among those hillocks which were formed as the result of catastrophic flood alluviation during the Pleistocene and have numerous cobbles, pebbles and nodules of chert over the surface. Because of the dangerous military waste remaining from the IraqIran war in the 1980s, the previous survey was devoted to limited areas of the site. But, we tried to take as many samples as possible in the present survey. However, the samples indicate a pattern of technological typology similar to what is known. What is visible among the Amar Merdeg 1 (Mr015) and 2 (Mr016) assemblages is numerous core-choppers and tested pebbles. We also found many partially bifacial chopper and unifacial choppers. But no bifacial tools were found, which could be a result of a sampling error. In Amar Merdeg 4 (Mr018) one hand-axe was discovered, although it is not so typical due to the later natural modification through time (Fig. 5.2). The raw material is mainly based on the chert, sandstone, and small amount of quartzite cobbles which are scattered over the surface of the site.

Mr023: some 5km to the southwest of Amar Merdeg, we found Paleolithic stone tools among later materials in an area of $c .2000 \mathrm{~m}^{2}$ bounded by fields. It should be noted that the site of $\mathrm{Mr} 023$ is not so prominent that it could be seen easily and it seems that was buried by Holocene alluviation. The Palaeolithic tools with denser concentration in west area of the site are distinguished from the later lithics by their different raw material, techno-typology and patina. Of these, one hand-axe with $10 \mathrm{~cm}$ in length and $7 \mathrm{~cm}$ in width, were discovered. The hand-axe is heavily retouched and only a small cortical area on both sides was unretouched (Fig. 3.2). Although this artefact was made of mudstone, chert and sandstone was the primary raw material at the site.

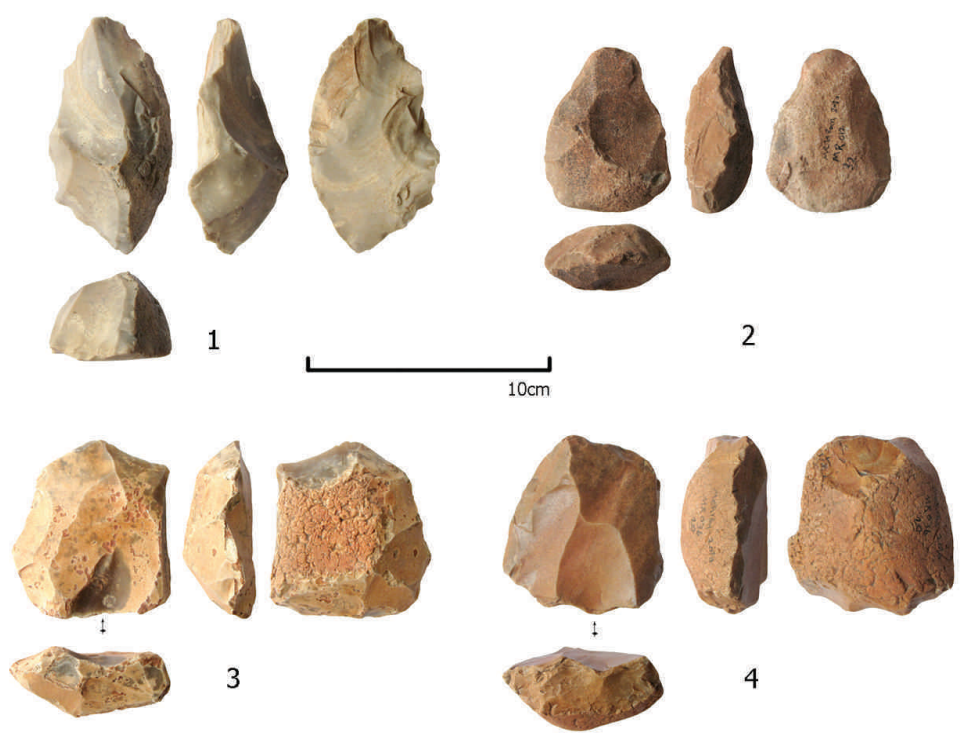

Fig. 5. The common presence of two techno-typologically different bifacial (top row) and Levalloisian (bottom row) tools on the Mehran Plain. 
In terms of the Lower Palaeolithic period, two points can be made: first, as the raw material to produce tools, the abundant chert stones on the surfaces of hillocks attracted the inhabitants of the plain. Second, all the localities in this period contain later Middle Palaeolithic remains, indicating continuity of occupation continuation, as suitable raw material was easily acquired. This, however, makes it difficult to identify the tools from each period, although they appear as two techno-typologically different bifacial and Levalloisian tools, respectively (Fig. 5). It should also be noted that the Lower

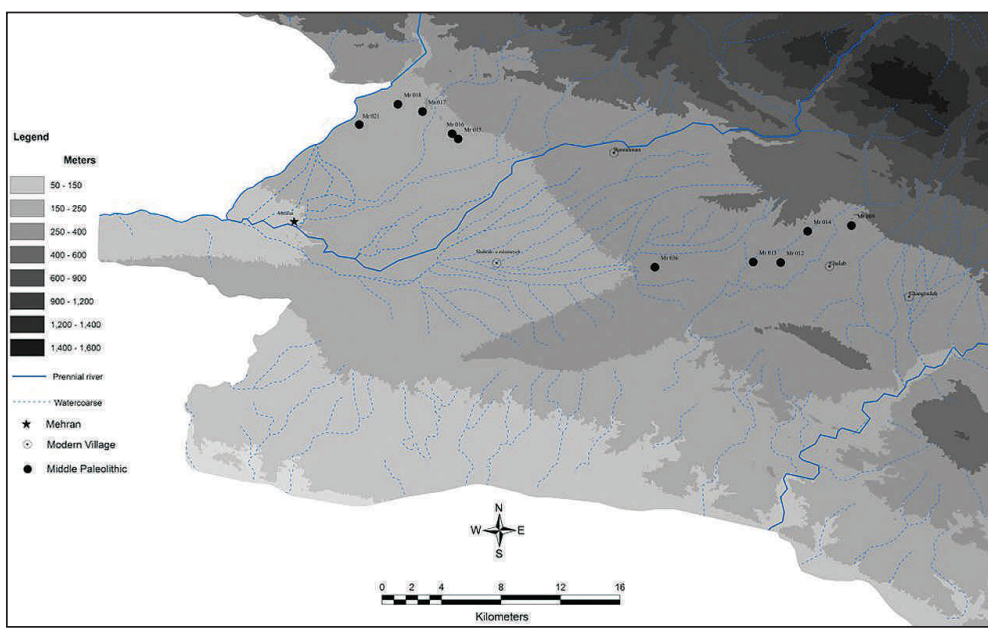

Fig. 6. Map showing the distribution pattern of Middle Palaeolithic sites on the Mehran Plain.

Palaeolithic tools have a heavier patina on the scar surface than those of the Middle Palaeolithic.

\section{Middle Paleolithic}

Since all the previous localities (except nos. Mr003 and 023) also yielded Middle Palaeolithic stone tools, the settlement pattern of this period somewhat resembles what is seen in the earlier period of the Lower Palaeolithic. Therefore, the geographical setting of these repetitive sites is here avoided and their typical stone tools are merely described. Moreover, the survey identified three new sites (Mr014-21-36; Fig. 6).

Mr009: most of the surface chipped stones at this site could be dated to the Middle Paleolithic period. Although no typical Levallois core was found, other indicators such as centripetal, bipolar and discoid cores along with their related tools are notable (Fig. $7.2,3,7)$. It should be mentioned that direct retouch was mainly used to produce tools such as scrapers.

Mr012: this site contained numerous techno-typologically Levalloisian tools over an
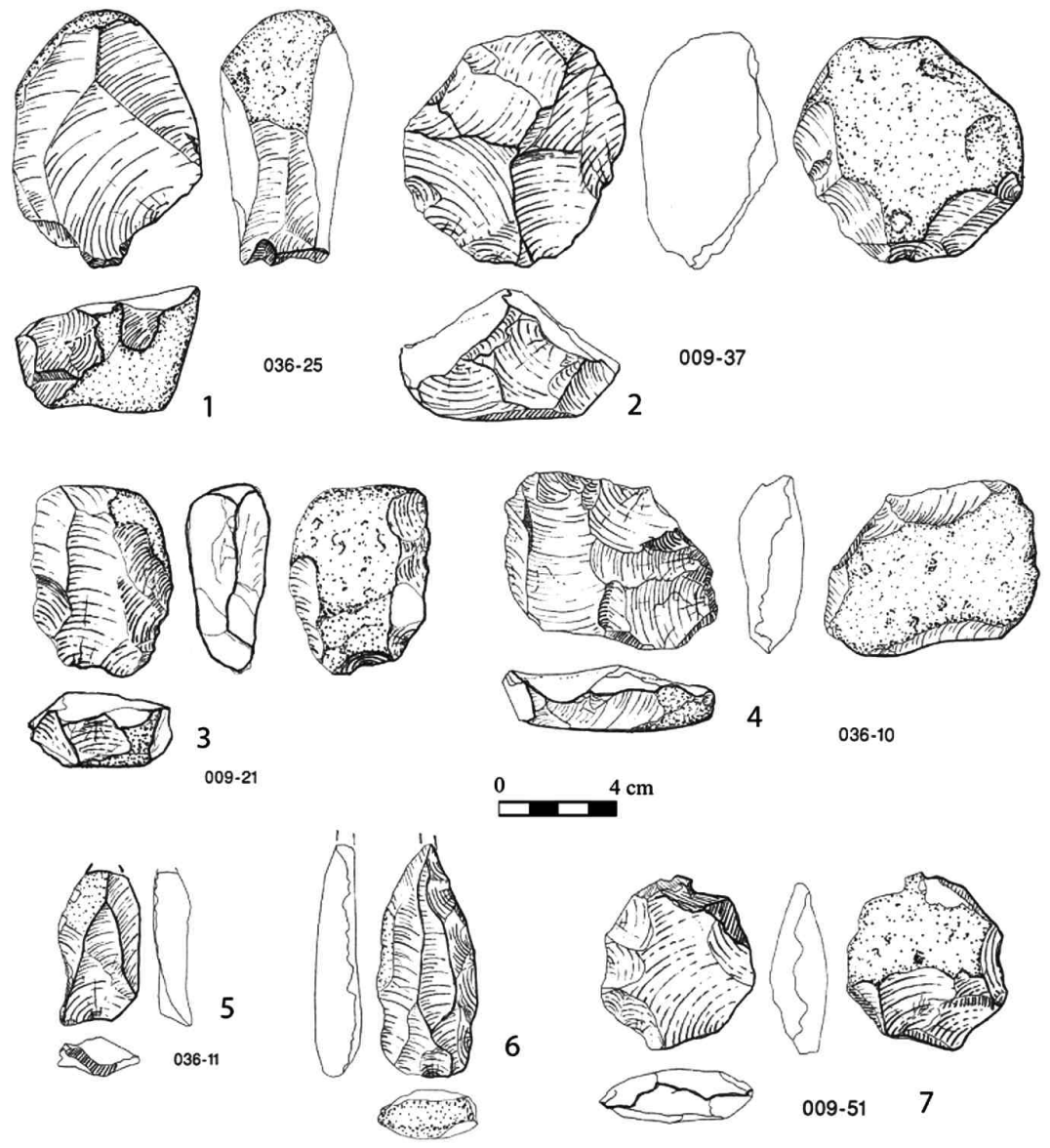

6

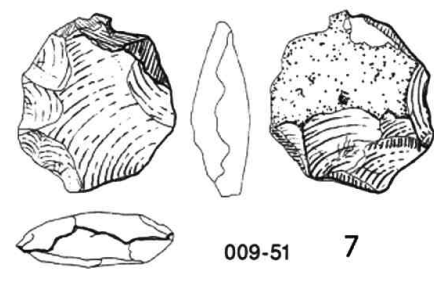

Fig. 7. Middle Palaeolithic stone tools from the Mehran Plain. 1 Levallois core; 2 centri-petal core; 3, 4 flake cores; 5 Levallois point; 6 side scraper; 7 discoid core. 
Mr013: the Levallois technique could be also attested at this site on the basis of the presence of some tools such as a Levallois blade core and a double-sided scraper made on an elongated flake.

Mr014: this locality is located about $2 \mathrm{~km}$ to the northwest of Chalab village in an area $c .2 \mathrm{~km}^{2}$ extending over several hillocks. Some single and multi-platform cores and different related debitages are visible on the surface, but no Levallois core

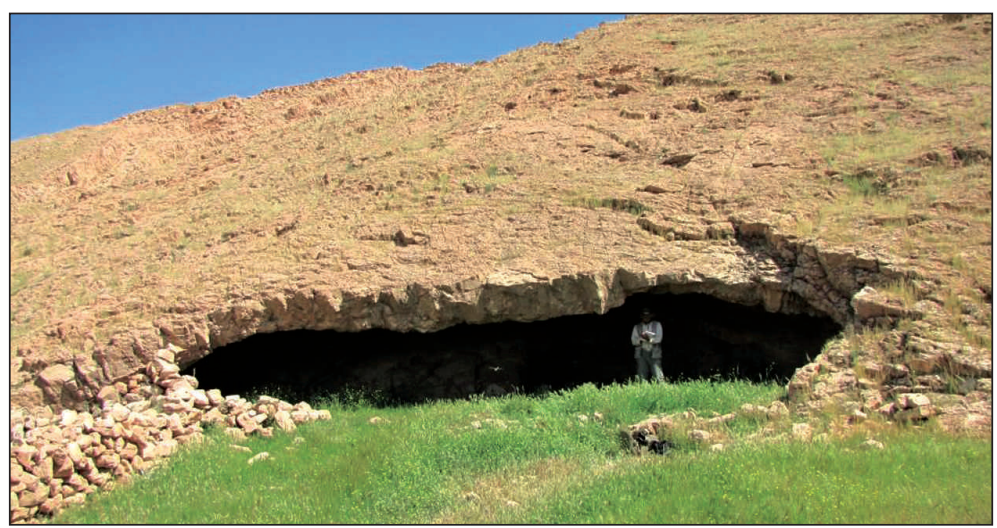

Fig. 8. General view of the Kellaw Pikeh rock shelter, looking north. was discovered, which could be a result of a sampling error. A scraper made on a débordante blade tentatively attributed to the Middle Palaeolithic is worth noting.

Mr015-16-17-18 (Amar Merdeg): most of the Amar Merdeg assemblage can be dated to Middle Palaeolithic with an emphasis on Levallois technology. Various tools such as a Levalloisian point with Chapeau de jendarme platform and various kinds of centripetal, discoid, single-platform and multi-platform cores are very common at the site.

Mr021: this site is located on the Chogha Khulami hillocks, covering about $1.2 \mathrm{~km}^{2}$ in area, $5 \mathrm{~km}$ to the north of Mehran Town on the left bank of the Konjan-Cham River. The numerous chert stones seen on the surface of these hillocks were used as raw material, as at Amar Merdeg. The collected assemblage indicates an emphasis on Levallois technology. Moreover, some tools were produced as a result of direct percussion. Techno-typologically the sampled tools, however, show a similar pattern to those of nearby Amar Merdeg, and centripetal, discoid, single-platform and multi-platform cores are also visible here. Although the site is near Amar Merdeg to the east, it has yielded no Lower Palaeolithic tools so far. This might be related to a sampling error; we await the discovery of earlier material.

Mr036: $8 \mathrm{~km}$ to the west of $\mathrm{Mr012}$, numerous chipped stones are scattered in a vast area which is not precisely defined. Levallois cores and tools are visible among the abundant chert pebbles and cobbles. Moreover, the most prominent indicator is a
Mousterian Point. Many other points with Chapeau de jendarme platforms should also be taken into account (Fig. 7.1, 4-6). However, various scrapers make up a high proportion of the assemblage.

\section{Upper Paleolithic and beyond}

The Upper Palaeolithic material is not as diagnostic as the Middle Palaeolithic. This prevents the easy attribution of the tools, which remains one of the most important research objectives for the future. However, a rock shelter known as Kelaw Pikeh has already been attributed to the Upper Palaeolithic (Nokandeh 2010). We revisited the site (Mr034) and took samples which are mainly based on different scrapers with no typical tool (Fig. 8). Two more sites were also dated to the Upper Paleolithic or even the Epi-Palaeolithic (Fig. 9).

Mr005: this site is located on the bank of the Lashtar stream in the easternmost part of the plain. Various tools such as scrapers, blades and cores made from red and light grey chert were collected from

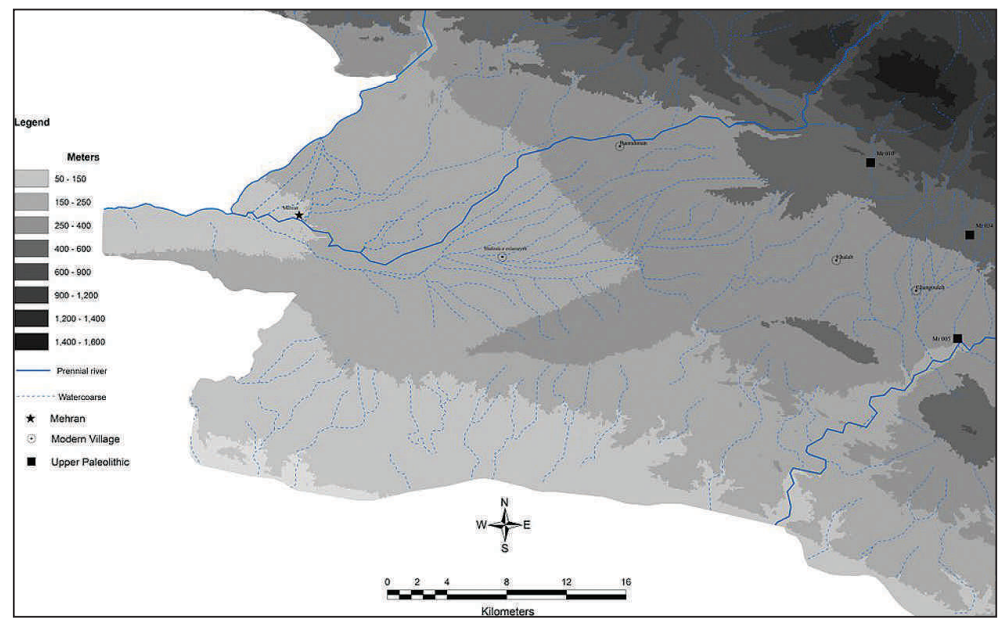

Fig. 9. Map showing the distribution of Upper Palaeolithic/Epi-Palaeolithic sites on the Mehran Plain. 


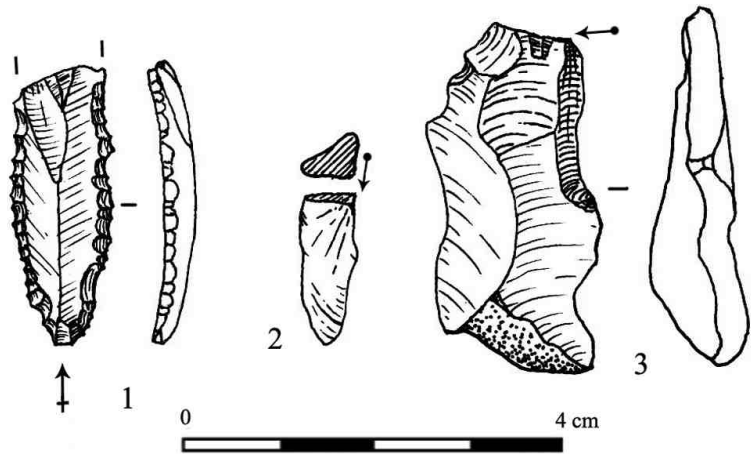

Fig. 10. Selected samples of Upper Palaeolithic/EpiPalaeolithic tools. 1 double-side scraper; 2 Burin spall; 3 Burin.

the surface. However, a burin was also found which was made on a blade and could be assigned to the Upper Palaeolithic (Fig. 10.3).

Mr010: some $5 \mathrm{~km}$ to the north of the Chalab village in the Daraw Palk Valley, a rock shelter is located which seems to have collapsed through time; a freshwater spring flows $300 \mathrm{~km}$ to the northeast which is used by local nomads as their main supply water. Chipped stones distributed among large stone slabs. The most significant tools are cores, blades, bladelets and scrapers, all of which are made from dark grey flint. No blade cores were found. Most of the tools are made on blades, of which a double-sided scraper with heavy retouch is notable (Fig. 10.1). Moreover, a burin spall was also discovered (Fig. 10.2) which could be taken as an indicator of possible Epi-Palaeolithic occupation.

Finally, it should be noted that, although some of these tools are attributable to both the Upper Palaeolithic and the Epi-Palaeolithic periods, we need more data, which is expected to be found on the northern parts of the plain.

\section{Discussion and conclusion}

The present survey indicates Palaeolithic occupation of the Mehran Plain at different times. Techno-typologically, we based our chronology mainly on materials from the nearby region of the Central Zagros to the north (Tab. 2).

The finds indicate that the Mehran Plain could have been occupied first in the later
Lower Palaeolithic. As mentioned above, the surface materials are hard to place within the Lower Palaeolithic, as in the case of the material found in the Hulailan Valley (Mortensen 1993). Most of the Lower Palaeolithic tools are chopping tools, which could not be dated individually to particular periods. However, the presence of bifacial tools and handaxes could be taken as a prominent indicator of Lower Palaeolithic occupation of the plain. These tools have been discovered in different areas, such as Gakia in Kermanshah (Braidwood 1960), Pal Barik in Hulailan (Mortensen 1993), Kuran Bozan Valley on the bank of the Seimarreh River (Alibaigi et al. 2011) or even in East Ajarbaijan to the north (SadekKooros 1976; Singer, Wymer 1978) as an indication of the Achuelian tradition. While one of the routes that early hominids supposedly took into Iran is

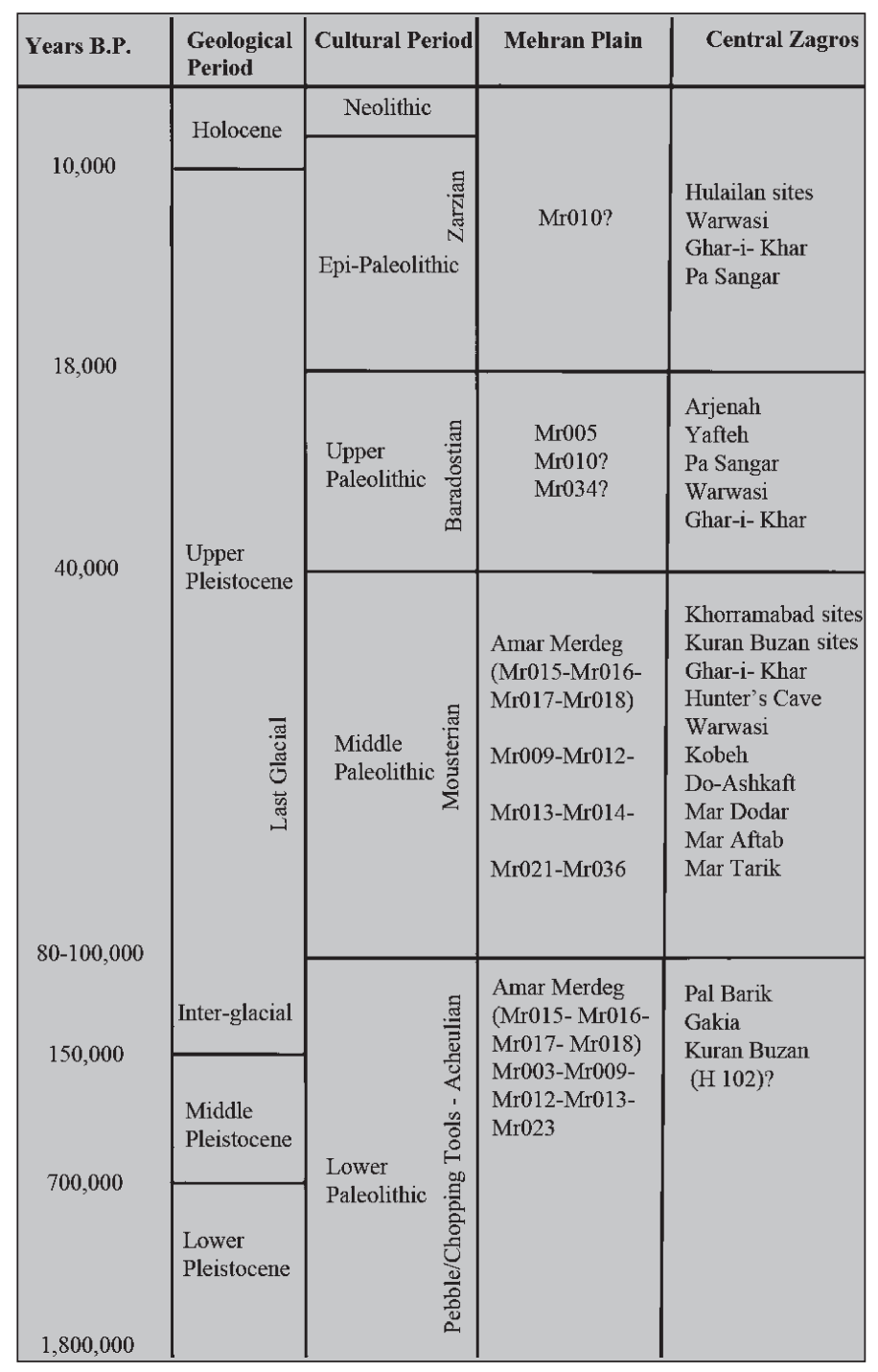

Tab. 2. Table showing the chronology of Palaeolithic sites found on the Mehran Plain in comparison with the Central Zagros (after Roustaei et al. 2004.699, Fig. 6 with some modifications). 
from northern Mesopotamia and along the southwestern foothills of the Zagros range (Rolland 2001), the recent remains from Mehran Plain are worth noting.

However, Middle Palaeolithic occupation is much more easily recognised than Lower Palaeolithic on the Mehran Plain, similar to what is seen in highland Zagros. Excavations at several sites in western Iran, such as Bisotun cave (Coon 1951; Dibble 1984), Warwasi rock shelter (Dibble, Holdaway 1993), Ghar-i-Khar (Smith 1986.18) and Konj and Arjenah caves (Baumler, Speth 1993; Hole, Flannery 1967) have provided a sufficient basis for dating the Middle Palaeolithic occupation, based mainly on the occurrence of the Mousterian tradition. Unlike these sites, the Mehran plain yielded open-air sites with Levalloisian tools, although the calcareous northern mountains need to be surveyed in future for possible caves and rock shelters with Middle Palaeolithic deposits. However, the present survey indicates that Palaeolithic occupation was concentrated primarily on hillocks where chert pebbles and cobbles of various sizes are visible. It seems that these hillocks were partly buried by the later Holocene alleviation, and therefore those areas which remained from the Pleistocene period contain Palaeolithic artefacts on the surface. We think the abundant raw materials attracted the Palaeolithic inhabitants at various times, resulting in the presence of different typo-technologically stone tools from both the Lower and Middle Palaeolithic periods. In terms of later occupation, the finds were so few that no conclusion may be drawn, and therefore it should be regarded as a significant issue for future research.

\section{ACKNOWLEDGEMENTS}

We thank M. J. Khanzadi, A. M. Shanbehzadeh, A. Yari, B. Pirani and R. Arjmandi in ICHO of Ilam Province for their work in obtaining the survey permit. We are also grateful to $\mathrm{Dr}$. $\mathrm{H}$. Fazeli for obtaining a place to study the finds at the Institute of Archaeology and S. Alibaigi for his helpful comments.

\section{Referenes}

Alibaigi S., Niknami K. A., Heydari M., Nikzad, M., Zainivand M., Manhobi S., Mohammadi Qasrian S., Khalili M. and Islami N. 2011. Palaeolithic open-air sites revealed in the Kuran Buzan Valley, Central Zagros, Iran. Antiquity 85(329), Project Gallery.

Baumler M. F., Speth J. D. 1993. A Middle Paleolithic Assemblage from Kunji Cave, Iran. In D. I. Olszewski, H. L. Dibble (eds.), The Paleolithic prehistory of the ZagrosTaurus. University Museum Symposium series 5. University of Pennsylvania, Philadelphia (PA): 1-73.

Biglari F. 2004. The Preliminary Observations on Middle Palaeolithic Raw Material Procurement and Usage in the Kermanshah Plain, The Case of Do-Ashkaft Cave. In T. Stollner, R. Slotta and A. Vatandoust (eds.), Persiens Antike Pracht: Bergbau, Hudwerk, Archäologie. Katalog der Ausstellung des Bochum: Deustsches Bergbau-Museums Bochum von 28 November 2004 bis 29 Mai 2005. Deutsches Bergbau Museum, Bochum: 130-138.

Biglari F., Nokandeh G. and Heydari S. 2000. Recent Find of a Possible Lower Paleolithic Assemblage from the Foothills of the Zagros Mountains. Antiquity 74: 749-750.
Biglari F., Heydari S. 2001. Do-Ashkaft: A Recently Discovered Mousterian Cave in the Kermanshah Plain, Iran. Antiquity 75: 487-8.

Biglari F., S. Shidrang 2006. The lower Paleolithic occupation of Iran. Near Eastern Archaeology 69: 160-68.

Braidwood J., Howe B. 1960. Prehistoric Investigation in the Iraqi Kurdistan. Studies in Ancient Oriental Civilization, no. 31. The Oriental Institute of the University of Chicago, The University of Chicago Press. Chicago.

Braidwood R. 1960. Seeking the World's First Farmers in Persian Kurdistan: A Full - Scale Investigation of Prehistoric Sites Near Kermanshah. Illustrated London News 237: 695-697.

Brantingham P. J. 2003. A Neutral Model of Stone Raw Material Procurement. American Antiquity 68: 487-509.

Brookes I. A. 1989. The physical geography, geomorphology, and Late Quaternary history of the Mahidasht project area, Qara Su Basin, central west Iran. Mahidasht Project Volume. Ontario Museum. Toronto. 
Coon C. S. 1951. Cave Explorations in Iran, 1949. The University Museum, University of Pennsylvania. Philadelphia.

Darabi H., Fazeli N. H. 2009. The Neolithic of the Mehran Plain: an introduction. Antiquity 83(322), Project Gallery.

Dibble H. L. 1984. The Mousterian Industry from Bisitun Cave (Iran). Palorient 18: 23-34.

Eyvazi J. 1995. Geomorphology of Iran. Payam-e Nour University Press. Tehran (in Persian).

Heydari S. 2004. Stone Raw Material Sources in Iran, Some Case Studie. In T. Stollner, R. Slotta and A. Vatandoust (eds.), Persiens Antike Pracht: Bergbau, Hudwerk, Archäologie. Katalog der Ausstellung des Bochum: Deustsches Bergbau-Museums Bochum von 28 November 2004 bis 29 Mai 2005). DeutschesBergbau Museum, Bochum: 124-129.

2007. The Impact of Geology and Geomorphology on Cave and Rockshelter Archaeological Site Formation, Preservation, and Distribution in the Zagros Mountains of Iran. Geoarchaeology 22(6): 653-669.

Hole F., Flannery K. V. 1967. The Prehistory of Southwestern Iran: a Preliminary Report. Proceedings of the Prehistory Society 33: 147-206.

Mohammadifar Y., Motarjem A. 2008. Settlement Continuity in Kurdistan. Antiquity 82(317), Project Gallery.

Mortensen P. 1993. Paleolithic and Epipaleolithic Sites in the Hulailan Valley, Northern Luristan. In D. I. Olszewski, H. L. Dibble (eds.), The Paleolithic prehistory of the Zagros-Taurus. University Museum Symposium series 5. University of Pennsylvania. Philadelphia: 159-187.

Nokandeh J. 2010. Archaeological survey in the Mehran Plain, South Western Iran. In P. Matthiae, F. Pinnock, L. Nigro and N. Marchetti (eds.), 6 ICAANE, Proceedings of the $6^{\text {th }}$ International Congress on the Archaeology of the Ancient Near East, Excavations, Surveys and Restorations: Reports on Recent Field Archeology in the Near East. Volume 2. Harrassowitz Verlag, Wiesbaden: 483-509.
Olszewski D., Dibble H. (eds.) 1993. The Paleolithic prehistory of the Zagros-Taurus. University of Pennsylvania Museum. Philadelphia.

Otte. M., Biglari F., Flas D., Shidrang S., Zwyns N., Mashkour M., Naderi R., Mohaseb A., Hashemi N., Darvish J., and Radu V. 2007. The Aurignacian in the Zagros Region: new research at Yafteh Cave, Lorestan, Iran. Antiquity 81(311): 82-96.

Otte M., Biglari F. and Jaubert J. 2009. Iran Paleolithic. BAR International Series 1968. Oxford.

Rolland N. 2001. The Initial Peopling of Eurasia and the Early Occupation of Europe in Its Afro-Asian Context: Major Issues and Current Perspectives. In S. Milliken, J. Cook (eds.), A Very Remote Period Indeed: Papers on the Paleolithic Presented to Derek Roe. Oxbow Books, Oxford: 78-94.

Roustaei K., Biglari F., Heydari S. and Vandati Nasab H. 2002. New Research on the Paleolithic of Lurestan, West Central Iran. Antiquity 76(291): 19-20.

Roustaei K., Vandati Nasab H., Biglari F., Heydari S., Clark G. A. and Lindly J. M. 2004. Recent Paleolithic Surveys in Luristan. Current Anthropology 45(5): 692-707.

Sadek-Kooros H. 1976. Early Hominid Traces in East Azarbaijan In F. Bagherzadeh (ed.), Proceedings of the IVth Annual Symposium on Archaeological Research in Iran, Tehran 1975. Iranian Center for Archaeological Research, Tehran: 1-10.

Singer R., Wymer J. 1978. A Hand-Ax from Northwest Iran: The Question of Human Movement between Africa and Asia in the Lower PalaeolithicPeriods. In L. G. Freeman (ed.), Views of the Past: Essays in Old World Prehistory and Paleoanthropology. Mouton, Hague: 13-27.

Smith P. E. L. 1986. Palaeolithic Archaeology in Iran. American Institute of Iranian Studies Monographs, Vol. 1. Studies by the University Museum, University of Pennsylvania. Philadelphia.

Vahdati Nasab H. 2011. Paleolithic Archaeology in Iran. International Journal of Humanities of the Islamic Republic of Iran 18(2): 63-87. 